Article

\title{
Social Factors Affecting Sustainable Shark Conservation and Management in Belize
}

\author{
Stephanie M. Sabbagh and Gordon M. Hickey* \\ Department of Natural Resource Sciences, Faculty of Agricultural and Environmental Sciences, \\ McGill University, Montréal, QC H3A 0G4, Canada; smsabbagh@gmail.com \\ * Correspondence: gordon.hickey@mcgill.ca
}

Received: 11 November 2019; Accepted: 10 December 2019; Published: 19 December 2019

\begin{abstract}
Predatory sharks contribute to healthy coral reef ecosystems; however their populations are declining. This paper explores some of the important social factors affecting shark conservation outcomes in Belize through a qualitative analysis of the shark-related activities, attitudes and perceptions among local stakeholders and their perceived relative ability to influence shark conservation policies. Drawing on key informant interviews and focus groups, respondents suggested that considerable demand for shark meat originates from markets in Mexico, Guatemala and Honduras, especially during Lent, driving larger-scale shark fishing operations within Belize waters. Different stakeholders reported a wide range of uses for shark products, and reported diverging perceptions concerning the status and value of shark populations in Belize, with conflicting attitudes towards their conservation. Such conflicting perceptions among stakeholders can pose a serious challenge to sustainable shark conservation and management, and ultimately undermine collaborative governance objectives. Belize shark conservation issues likely need to be addressed at the scale of the Mesoamerican Barrier Reef, perhaps by taking a transboundary approach that better accounts for the roles and responsibilities of stakeholders from Belize, Mexico, Guatemala and Honduras.
\end{abstract}

Keywords: fishery management; small scale fisheries; rural livelihoods; Mesoamerican Barrier Reef; social-ecological systems; stakeholder analysis; resource systems

\section{Introduction}

Predatory sharks feed on the animals below them in the food web and play an important role in maintaining healthy marine ecosystems $[1,2]$, and ensuring the resilience of coral reefs $[1,3-5]$. There is increasing scientific concern over the fishing of sharks and rays [6-8], which has made them "among the most valuable and vulnerable species in the sea" [9]. Sharks have biological traits, such as taking a long time to reach sexual maturity, long gestation period, carrying few young, and a long life span that make them especially vulnerable to overfishing [10,11]. There are now a wealth of studies showing worldwide declines in multiple shark species, both coastal and oceanic, including local extinctions $[2,7,9,12-15]$ and near extinctions $[16,17]$. As a result, the protection of sharks and rays is a recognized priority in international marine conservation [5,18-23].

Declines in shark populations have been attributed to over-harvesting (resulting from directed and undirected catches) and by-catch [19,22]. The global ocean is estimated to have experienced a $90 \%$ loss of large predatory fish, while the Gulf of Thailand alone "lost $60 \%$ of large finfish, sharks and skates during the first five years of industrialized trawl fishing" [8].

Science and policy gaps have been identified as a major challenge to sustainable shark conservation [23], with a lack of synthesis on shark movement, habitat and partitioning data often limiting conservation and management strategies [22]. A major political and organizational challenge is 
the transboundary nature of shark migration throughout their life stages, requiring collaboration across national boundaries [22,24]. The need for unilateral, bilateral and multilateral action has often been identified $[19,20,22,24,25]$ but remain a serious political gap (see [26] for details on the coordination of governance, conservation and management of shared-stocks and living resources). In 1999, the Food and Agriculture Organization of the United Nations (FAO) released the International Plan of Action for the Conservation and Management of Sharks (FAO-IPOA-Sharks [18]) as an international mechanism to promote national shark conservation and management. However, as reported in 2011 by Techera and Klein [23] this is a voluntary international instrument with many nations either not adopting it [2], not developing and implementing their shark plans [27] or not adequately reporting their shark landings [5].

Researchers, governments and conservationists agree that the management of sharks is challenging but a priority $[5,11]$. Despite a growing number of conservation initiatives, Illegal, Unreported and Unregulated (IUU) fishing remains a major issue [28,29] and marine protected areas and shark sanctuaries do not necessarily translate into compliance $[28,30]$. Social non-acceptance also poses a serious challenge to successful shark conservation and management [30-34], and can potentially accentuate their decline if not addressed [35-37]. There is now a recognized need to understand how different communities relate to sharks and then consider these relationships in marine policies $[23,38]$. Different stakeholders, their values, interests and power relations are also likely to have a significant impact on shark conservation outcomes and need to be understood [39-41].

\section{Shark Conservation in Belize}

Belize is home to the Mesoamerican Barrier Reef (alternatively called the Belize Barrier Reef or Belize Coral Barrier), the second largest reef system in the world and a World Heritage Site [42]. This reef sustains the livelihoods of many coastal communities in Belize and is a major asset to the country [43]. The reef also harbors "one of the most diverse reef ecosystems in the world, with all the main types of reef represented" [44] and is home to many threatened and endangered species of shark [45]. Research on sharks is relatively recent in Belize. In the last two decades, long-term population studies have contributed to the understanding of the local shark populations, habitat preferences and behavioral patterns for the Caribbean reef shark (Carcharhinus perezi) and the Nurse shark (Ginglymostoma cirratum) [46,47]. Some of this local research has assisted in the listing of the Caribbean reef shark on the International Union for the Conservation of Nature (IUCN) Red List of Threatened Species [48]. According to the IUCN, at least 16 predatory shark species have their distribution on the Belize reef and appear on the Red List of Threatened species (IUCN Red List website accessed 26 October 2019 [49]. At the same time, sharks are being heavily fished in Belize waters without strong protecting laws, except in the case of the Whale shark (Rhincodon typus) [48,50], and more recently in 2011 [51] the Nurse shark (Ginglymostoma cirratum) (Regulation 26:02 to 26:07) which are both protected species.

This paper explores some of the complex social factors affecting sustainable shark conservation outcomes in Belize, using (to the extent possible) the words and stories of stakeholders concerning their shark-related activities, attitudes and perceptions, as well as their perceptions of the other stakeholders involved in shark management. The results highlight some of the political complexities associated with formally protecting sharks in Belize, offering insights into the relationships between sharks and traditional livelihoods, social customs and the role of communities in sustainable natural resource management. Conflicting viewpoints are identified within and between stakeholder groups, potentially leading to feelings of social alienation and resulting in non-compliance with shark conservation initiatives, irrespective of the urgency of scientific call for action [52,53]. In what follows we provide an overview of different social issues associated with shark conservation in Belize. We then contrast and compare the self-reported shark-related use activities, attitudes and perceptions among different stakeholder groups and consider their relative ability to influence shark conservation policies to help inform management and policy. 


\section{Methods}

This research followed an exploratory case study research design, using grounded theory methods such as constant comparison and pattern matching to analyze and interpret qualitative data [54-56]. Case study research is considered the preferred approach when the investigator has little control over events, and when the focus is on contemporary phenomenon operating within a 'real-life' context [56]. Grounded theory provided a systematic approach to discovering substantive theory from qualitative data while providing a more in-depth understanding of the complex policy challenge [54,57]. Our research questions focused on shark and shark fisheries issues within Belizean waters. We acknowledge that Belize also has vessels flying the Belizean flags that operate on the high seas [58], but this was beyond the scope of our research. We also focused only on predatory shark species and not all elasmobranch that may be relevant to conservation and management policy.

\subsection{Study Location}

The Mesoamerican Barrier Reef extends from Mexico in the north to Guatemala and Honduras in the south [42]. The majority of the reef lies in the jurisdiction of Belize, bordered by the Caribbean Sea to the east. Due to its location in Central America and the Caribbean Sea, Belize has a diversity of cultures and traditions. Ethnic communities include the Garifuna, the Creole, the Maya, the Mestizo (Spanish/Latino), Mennonites, East Indians, East Asians and expatriates. Data for our case study were collected predominantly in Punta Gorda town and Placencia village (Figure 1). These sites were selected due to the presence of diverse stakeholder groups and interests (recognizing that most government departments are in Belize City), the proximity to the reef (both are gateways to important marine reserves and fishing grounds), and their cultural diversity (Punta Gorda is mainly a Maya and Garifuna community while Placencia is predominantly Creole in origins).

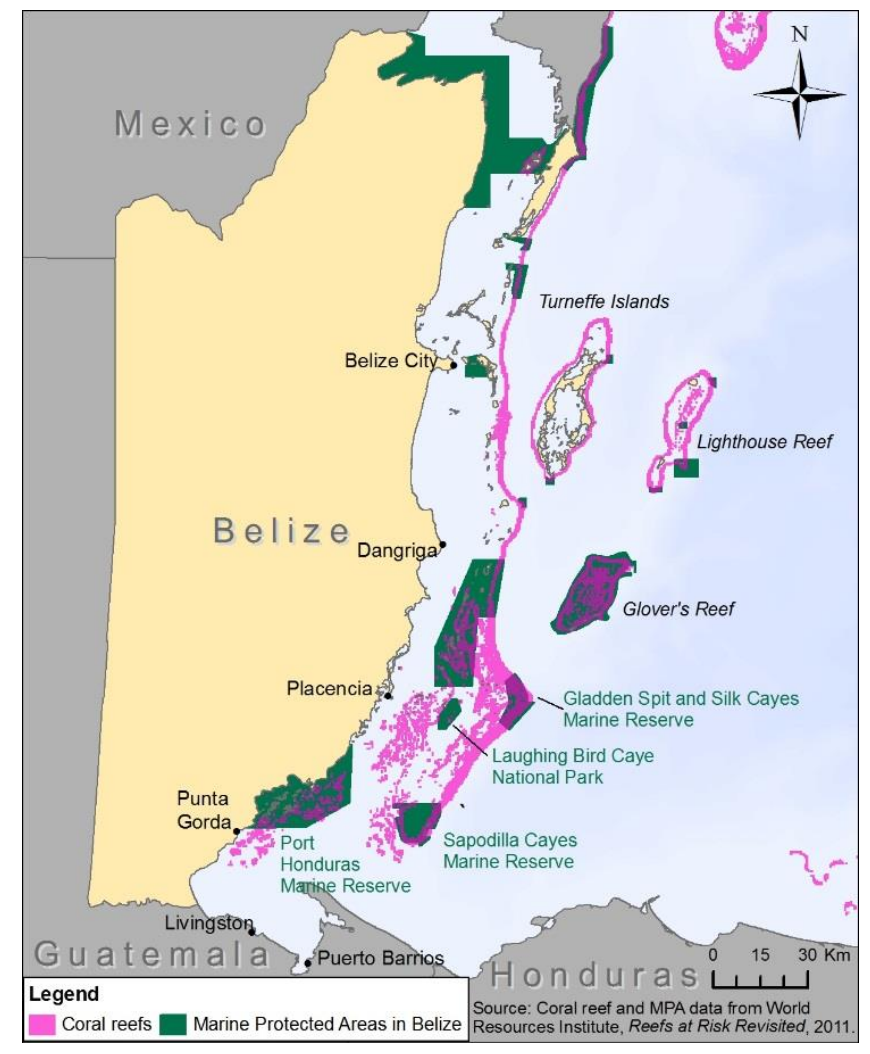

Figure 1. Map of Belize and Mesoamerican Barrier Reef, Central America, showing study sites, Marine Protected Areas and neighboring country towns mentioned in the study. Map created by Katie Reynar for this study, using the World Resource Institute Source: Reefs at Risk Revisited 2011. 
There are important cultural differences between our study sites, with different religious beliefs, food habits and customs evident.

Punta Gorda is the major town located in the southernmost district of Toledo (Figure 1). The south is the least developed part of Belize, diverse ethnically and an area where tourism is taking off $[59,60]$. Port Honduras Marine Reserve, the Snake Cayes and the Sapodilla Cayes Marine Reserve are all accessible from Punta Gorda. The town is primarily home to Maya and Garifuna People [61], with an increasing Chinese community and recently a growing expatriate community from the USA, Canada and Europe. Garifuna People have their own religious beliefs and speak the Garifuna language. Most also speak English, or the local Belize Kriol.

Placencia, further north in the Stann Creek district, is located along the Placencia peninsula. The reef there is located closer than in Punta Gorda, where the major tourist attractions of Laughing Bird Caye National Park and the Gladden Spit and Silk Cayes Marine Reserve are quickly accessible by boat. Placencia has seen tourism rapidly increase since the 1980s [62]) and the village continues to change with expatriate numbers generally increasing. Placencia is predominantly a Creole village $[59,61]$, another major culture in Belize with different food, habits and customs than Garifuna People, with an increasing Chinese and expatriate community.

\subsection{Data Collection}

Qualitative data were collected between May and August 2011 through key informant interviews [63], informal participant observations [64], focus groups [65,66] and document analysis [67]. Informed consent was obtained from all participants prior to data collection using signed consent forms detailing the purpose of the study, the rights of participants, including their right to withdraw from the study at any time without consequence, and the roles and responsibilities of the researchers, including the contact information for McGill's Research Ethics Officer. Data were collected primarily through semi-structured, face-to-face interviews with key informants, initially selected purposively $[56,68,69]$ and then through snowball sampling [70]. A pre-test of our interview guide was conducted with non-participating stakeholders to verify comprehension and to minimize bias.

Key informants were purposively selected from six predetermined shark-related stakeholder groups: (1) Government, (2) fishers, (3) restaurant, (4) non-governmental organizations (NGOs); (5) tourism sector and (6) academics and scientists. Formal face-to-face, semi-structured interviews were the primary means of data collection (see Table 1). Questions were allowed to evolve with the interviews. The interview guide included brief demographic information on respondents and their family members followed by closed and open-ended questions to stimulate reflection on shark-related issues [57]. In total, 38 semi-structured interviews were conducted in Placencia, Punta Gorda, Belize City and Independence.

Table 1. Participants in our semi-structured interviews by location and stakeholder group.

\begin{tabular}{lcccc}
\hline Sector & Punta Gorda & Placencia & Other & Total \\
\hline Fishers & 4 & 5 & 2 & 11 \\
Tourism & 2 & 9 & 0 & 11 \\
Government & 2 & 0 & 5 & 7 \\
Academic & 1 & 0 & 0 & 1 \\
NGO (incl. biologists and rangers) & 1 & 3 & 1 & 5 \\
Restaurant & 0 & 3 & 0 & 3 \\
Total & 10 & 20 & 8 & 38 \\
\hline
\end{tabular}

Three focus groups were held once the interviews were completed: two with all stakeholder groups invited (one each in Placencia and Punta Gorda) and one with only fishers in Punta Gorda. Table 2 presents a summary of the focus group participant profile. These focus groups allowed open discussion on the emerging findings from the interviews and provided new information. This served 
to triangulate our data and strengthen the trustworthiness of our results [71]. Document analysis (including media, public reports, government documents, etc.) and informal observations (e.g., at local fish markets and cooperatives) were also used to triangulate the data collected through interviews and focus groups.

Table 2. Focus group participants by stakeholder groups and locations.

\begin{tabular}{lcccc}
\hline \multirow{2}{*}{ Sector } & \multicolumn{3}{c}{ Focus Group Meetings } & \multirow{2}{*}{ Total } \\
\cline { 2 - 4 } & Punta Gorda (1) & Punta Gorda (2) & Placencia (3) & 18 \\
\hline Fishers & 4 & 8 & 6 & 4 \\
Tourism & 2 & - & 2 & 3 \\
NGO (incl. biologists and rangers) & 2 & - & 1 & 25 \\
Total & 8 & 8 & 9 & 3 \\
\hline
\end{tabular}

\subsection{Data Analysis}

Interviews and focus groups were recorded and fully transcribed. The transcription retained the interviewees' exact words, whether grammatically correct or not, and were written mostly in Belizean Kriol-the language used in most interviews, but also in English and Spanish. Expressions and pauses were also transcribed. This allows the mood of the interview to be captured. Rubin and Rubin [63] refer to this as "precise transcription" which adds 'flavor' to the narrative. Each interview transcript was then manually coded using the computer software MAXQDA 10. Coding is a dynamic process to reduce or 'distill data' [57] and to sort patterns which enabled us to derive categories without forcing the data [54]. This process involved recursive and continuous coding and memo writing while analyzing the qualitative data [57]. Content analysis of documents (e.g., news reports and government documents) was used to supplement and validate the information gathered through our interviews and focus groups where possible [56]. Following [72], we present our results based on the responses of participants as follows: the words "generally", "many", "most", "often", "the majority" indicate $>50 \%$ of the relevant respondent group; the words "some", "a few" and "a number of" indicate response from $10 \%$ to $50 \%$ of the sample; and (c) "all" and "one" were also used occasionally.

Stakeholder Analysis [69] was also applied to our qualitative data to better understand how the stakeholders perceived their role in policy-making relative to others [39,71,73]. Based on the emergent themes and categories obtained, we ranked the stakeholders according to their interests in shark protection and their perceived relative influence on policy-design in Belize. Stakeholder position reflected the general interest of the stakeholder group towards shark conservation policy and fell under the following spectrum ladder: opposed, moderately opposed, neutral, moderately support or support. A stakeholder's position on the spectrum was determined by compiling the self-reported position of the key informant with the indirect information gathered from other stakeholders.

It is important to note that our analysis was conducted within a limited time frame, providing only a 'snapshot' of the situation at a particular time. We recognize that the stakeholder landscape is not stable and that the views and perspectives reported can change quickly due to internal or external factors, as can the perceived position of the stakeholders in policy $[74,75]$. Further, while we categorized the interests and influence of stakeholder 'groups' to facilitate analysis, in reality, these groups are not mutually exclusive [39].

This research was conducted as part of the lead author's M.Sc. Thesis degree at McGill University. All field research protocols were reviewed and approved by the McGill University Research Ethics Board (REB File \#: 959-0311) prior to data collection. The project also received a local research permit from the Belize Fisheries Department (\#000036-11). 


\section{Results}

Respondents understood the term 'shark' differently: Some included whale sharks with predator sharks, others differentiated between reef and whale sharks. In most cases, it was necessary for the researchers to clarify and make the distinction depending on the question being asked. Table 3 presents a summary of the results using direct quotes.

\subsection{Perceptions Concerning Shark Conservation and Management}

\subsubsection{Shark Use in Belize}

More than half of our respondents stated that Belizeans do not generally consume sharks. According to a government official: "it's not a topic we usually discuss [eating sharks]. [ ... ] We don't eat shark unless we eat panades. As well, that's limited, the use is limited, quite limited." Most respondents explained that sharks are mainly consumed as panades, a deep-fried, bite-sized corn dough stuffed with seasoned ground fish. Three panades usually sell for one dollar Belize (0.50 USD) from street carts or snack shacks. Practicality is one reason that emerged for using shark meat because there are no bones to clean out. Local shark consumption was reported as being mainly a function of bycatch. A Fisheries Department officer confirmed: "we're not used to seeing a lot of sharks on the market". Both authors happened to observed shark for sale in local fish markets while conducting the research (Figure 2).

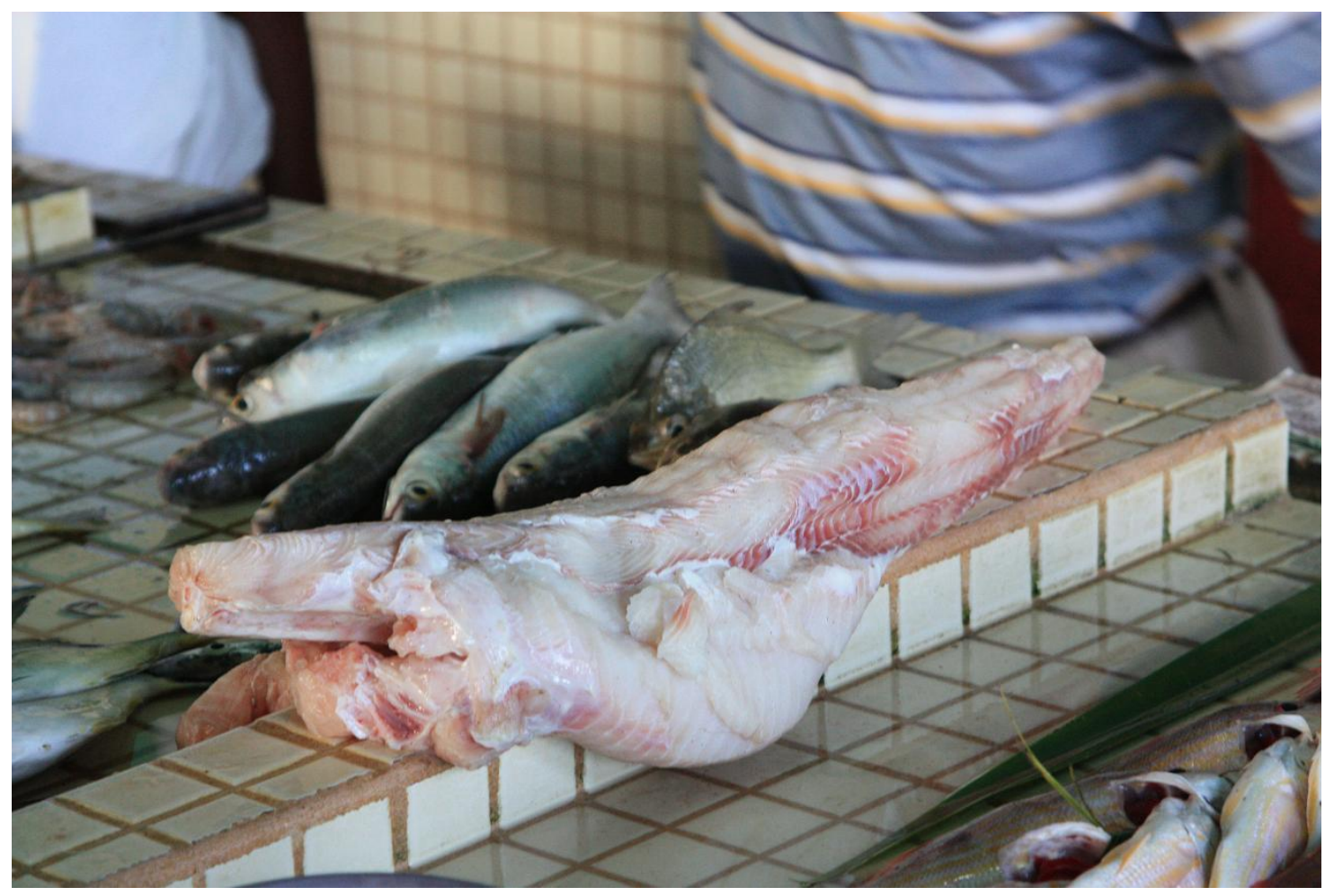

Figure 2. Shark meat for sale in local fish market. 
Table 3. Summary of the shark conservation and management-related perceptions reported by key informant.

\begin{tabular}{|c|c|c|}
\hline Theme & Perception & Sample Statements from Key Informant \\
\hline \multirow{4}{*}{$\begin{array}{l}\text { Local } \\
\text { consumption of } \\
\text { shark products }\end{array}$} & \multirow[b]{2}{*}{ Negative } & "[panades] that's one of the main uses of shark, [ .. ] they don't buy shark for example a shark fillet [ ... ] they don't consume that." Government \\
\hline & & $\begin{array}{l}\text { "every now and again they might catch a Hammerhead in a gillnet for example, which is an accidental catch and I do know that, I saw one in the market last } \\
\text { week. However, that's the first time I ever seen a shark, hammerhead anyway in the market here and it's not common thing" Tourism operator }\end{array}$ \\
\hline & \multirow{2}{*}{ Positive } & $\begin{array}{l}\text { "shark is good for medicine, it's good for the shark oil. [ ... ] They use the liver a lot, and I think that's bad thing for the people to want to protect the shark } \\
\text { because by doing that, they have to give up natural medicine and go to doctor and half the old people don't believe in doctors." Fisher }\end{array}$ \\
\hline & & $\begin{array}{l}\text { "if the people know how to clean it, then you can't tell the difference." Fisher } \\
\text { "hammerhead and they were selling the fins and I also have seen fins in the Chinese stores here." Tourism operator }\end{array}$ \\
\hline \multirow{4}{*}{$\begin{array}{l}\text { International } \\
\text { consumption of } \\
\text { shark products }\end{array}$} & \multirow{4}{*}{ Positive } & "They have Chinese people in Belize, in Mexico and in Guatemala that buy the shark fins for export." Fisher \\
\hline & & "my brother fish for shark during lent season. Have market for it. [ ... ] He got partner from Guatemala". NGO \\
\hline & & "it's for the market, for the Asian market. In Guatemala it has a very high value [... ] and the meat, well stays in Guatemala." Government \\
\hline & & "they are taken across to Honduras actually, most of the sharks that are caught they are not sold here in Belize. Tourism operator \\
\hline \multirow{5}{*}{$\begin{array}{l}\text { Illegal and } \\
\text { unreported shark } \\
\text { fishing }\end{array}$} & \multirow[b]{2}{*}{ Negative } & $\begin{array}{l}\text { "they have fishing license, so we call them Guatemalans but they [... ], do in most cases fish legally in Belize, many times they export their produce illegally, } \\
\text { but while they're fishing in Belize they're legal because they usually, in most cases have Belizean fishermen licenses." Government }\end{array}$ \\
\hline & & $\begin{array}{l}\text { "those people who they accuse, of being Guatemalans are Belizeans citizens you know. They live over there, and they trade over there. [ ... ] some of the } \\
\text { fishermen from this side now are jealous, oh you guys are aliens, you guys don't belong here, but that's because they have already market over there, which they } \\
\text { don't really have here." Government }\end{array}$ \\
\hline & \multirow{3}{*}{ Positive } & "people come into our country, illegally, setting nets and stuff under our noses you know [ ... ] they take mainly sharks [ ... ] they take everything." Fisher \\
\hline & & "they have Belizean license, but [ ... ] he's illegally selling that fish over the border, he have to have an export license to export shark." Tourism operator \\
\hline & & "it has been many years that tese guys just come across do their harvest and they go back home ... how they manage, I don't know." NGO \\
\hline \multirow{7}{*}{$\begin{array}{l}\text { Shark population } \\
\text { decline }\end{array}$} & \multirow{3}{*}{ Negative } & right now, there's a lot of sharks, no lies, a lot, a lot of sharks,..., especially Bull sharks when the snappers come out there" Fisher \\
\hline & & $\begin{array}{l}\text { "At about, } 13 \text { years old [ ... I I remember catching fish, lots of fish, no problem for example for sharks, you never have to worry about sharks coming and taking } \\
\text { fish off your line [ ... ] compare then to now, when you fish out there, there's so many sharks, taking away your fish from your line" Fisher }\end{array}$ \\
\hline & & "They come to the surface, I have marks on my boat that they bite the boat and missed the fish. They are horrible." Fisher \\
\hline & \multirow{4}{*}{ Positive } & $\begin{array}{l}\text { "well certainly there is less, I remember as a kid growing up in the Sapodilla Cayes, every evening, you would see the sharks coming into the reef and you would } \\
\text { just see their dorsal fin and so, and it was a part of your evening ritual, you would just sit on the beach and watch them come in, sometimes you'd set a line and } \\
\text { catch them... Obviously you don't see them anymore, so you know that there is a lot less than there were." Government }\end{array}$ \\
\hline & & "I used to pull long lines fishing for sharks but that was outside the reef, but from my time to now, shark is depleting real fast." Fisher \\
\hline & & $\begin{array}{l}\text { "I could stand on the Punta Gorda pier and see } 8 \text { foot sharks swimming. [ ... ], loads and loads and loads and, not anymore. [ ... ] in '72 the fishing pressure } \\
\text { was heavy back then and it went right through the 80s immensely heavy and that's when they were decimated". NGO }\end{array}$ \\
\hline & & $\begin{array}{l}\text { "they used to catch, come in with big shark and big turtle have them tie up under the coconut tree down by the co-op, I see it when I meh a lee boy, now we noh } \\
\text { see, don't see the shark no more." Tourism operator }\end{array}$ \\
\hline
\end{tabular}


Table 3. Cont.

\begin{tabular}{|c|c|c|}
\hline Theme & Perception & Sample Statements from Key Informant \\
\hline \multirow{10}{*}{$\begin{array}{l}\text { Shark } \\
\text { conservation }\end{array}$} & \multirow{3}{*}{ Negative } & $\begin{array}{l}\text { "I wouldn't say no, I would say we have to study it [ ... I because they are closing down a lot of the fisheries and without any expertise [ ... I I think they're } \\
\text { abusing us, because these laws can easily be made, and it's not made for a specific time, without any proper studies, and it's not fair [... ] the fishermen must } \\
\text { find their way of making their living, so you have to have a balance". Fisher }\end{array}$ \\
\hline & & $\begin{array}{l}\text { "to say fully quit shark fishing, I think it's too early to think it, give us a chance and let's see ok, if you tag 500, then we know we have you know, something to } \\
\text { work on, just not by [... ] telling us oh the shark are declining." Fisher }\end{array}$ \\
\hline & & $\begin{array}{l}\text { "they're not fishing sharks, they're fishing other species, they're obviously a bit of a menace, cause they will bite their catch in half as they're pulling it in". } \\
\text { Tourism operator }\end{array}$ \\
\hline & \multirow{4}{*}{ Positive } & $\begin{array}{l}\text { "I want the people to catch no shark [...] no shark at all [...] because the people that catch the shark in Belize are not Belizean, [... ] and the shark they don't sell } \\
\text { it in Belize." NGO }\end{array}$ \\
\hline & & $\begin{array}{l}\text { "close down the shark fishing and I think dat a good thing because that a save the reef as well because if you no have no sharks the reef no a survive without main } \\
\text { predator in the water." Fisher }\end{array}$ \\
\hline & & $\begin{array}{l}\text { "I had a German guy who paid me to go and find shark [ ... I I get frequent people ask me to, we actually have the dive sites that we call the Shark Hole, because } \\
\text { of people want to see shark." Tourism operator }\end{array}$ \\
\hline & & $\begin{array}{l}\text { "they get excited all the time [ ... ] most tourists, Nurse sharks get them excited, I have few tourists come and say oh I want, I'd love and see some Black tip, or } \\
\text { Bull shark". Tourism operator }\end{array}$ \\
\hline & \multirow{3}{*}{ Undecided } & $\begin{array}{l}\text { "well before you can do that you have to get the science, you know I mean we are a little bit tired of people coming and telling us to conserve this that and they } \\
\text { don't have any scientific data or basis to back up why." Government }\end{array}$ \\
\hline & & $\begin{array}{l}\text { "my position is that if the data is showing that populations of sharks anywhere is declining [ ... ], we put in place mechanisms that will ensure that their } \\
\text { populations will return [ ... I I think we can't just protect it and protect it forever, we have to protect it, collect the data that support the reason for its protection } \\
\text { and then there must be a time when we could allow people to do what they traditionally are doing." Government }\end{array}$ \\
\hline & & $\begin{array}{l}\text { "I think there should be a lot of discussion and come up [ ... ] something that that makes the fishermen, and the tourism, people involved in tourism, um, } \\
\text { equally happy you know? [ .. ] Instead of saying no you can't touch the sharks, because then, it would also create a problem". Tourism operator }\end{array}$ \\
\hline
\end{tabular}


The smell of shark, and that it is often salt-preserved when processed, emerged as the primary reasons why some interviewed Belizeans reported not eating shark. The thought of eating sharks to many of these respondents manifested facial expressions of disgust due to the smell: "I cannot even eat sharks, the smell fieou!" described a fisherman and tour guide from Placencia. Another reason reported was that they don't need to eat salt-preserved fish (often shark), as a senior fisher explained: "they (neighboring countries) have to preserve the shark with salt, and Belizeans have gotten away from eating fish preserved with salt now, they want to eat fresh fish." This practice would have originated when ice and coolers were not readily available. The practice was largely abandoned in Belize; however it has remained in the other countries surrounding the Mesoamerican Barrier Reef.

In contrast, culture and taste emerged as reasons why some Belizeans enjoyed eating sharks. When asked whether sharks were considered to be a part of the Belize culture or diet, a Placencia fisher explained that "in Seine Bight yes, but not here. In Seine Bight you can sell a shark in less than 5 min." Seine Bight is predominantly a Garifuna village along the Placencia peninsula. Some respondents enjoyed eating shark because of its unique taste once cooked. The Chinese community living in Belize was also identified as consuming sharks. Some respondents speculated that shark meat might be used to mimic that of other fish species in demand. Fish mimicry was a controversial topic during our interviews [76,77] in July 2011 after researchers from the USA found that the fish sold at Belize markets, grocery stores and to restaurants were often mislabeled as snapper or grouper [78].

Medicinal use of shark products was another reported value, particularly for older generations of Belizeans. Shark oil was considered a multi-purpose remedy at a time when pharmacies were not common. A respondent reflected on his youth: "when we were kids I guess there was less access to pharmacies, so shark oil was thought to be good for almost any sickness you could find. I remember they used to give it to us as kids for asthma". Shark oil is still used as medicine by many people in Belize.

\subsubsection{International Use of Sharks Caught in Belize}

Our respondents explained that Belizean-caught sharks were consumed mainly in the three neighboring countries of Mexico, Guatemala and Honduras, described as being an important part of their culture, traditions, and religion, with the popularity of eating salt-preserved fish and food preferences related to the Roman Catholic Lenten season considered key drivers. Livingston and Puerto Barrios, two coastal towns in Guatemala that are quickly accessible by boat from Punta Gorda (see Figure 1), were reported as selling sharks caught in Belize. "They shift them deep in Guatemala City [ ... ] last time I went to Livingston I went to an area, it was on the dock, there were so many Nurse sharks, just the fillet on the docs, bags and bags of Nurse sharks there".

Belizean fishers expressed frustration because of the blame they felt they received for the activities of foreign fishers in Belize: "they have a bigger population, the fish can be transported way back in the inland because it's brine [ ... ] but again, they've been blaming us." Foreign fishers from the neighboring countries were described as entering Belize waters and fishing sharks for months at a time, especially prior and during Lent. This was strongly supported by the majority of our respondents: "we know that a lot of Guatemalans live off the money they make from between October and March, April, you know the salted fish and the shark fin are key to their economy so they would bring as much nets as they can". Questioning the legal status of these foreign fishers emerged as another major theme in the interviews and focus groups across all stakeholder groups. A complex mixture of legal and illegal shark fishing activity was described by our respondents (see Table 3). There was also a perceived demand for shark fins from the growing Asian community in the region. Respondents described a market for shark products in the region, where residents in the Asian community reportedly exported fins to Asia. Our research did not validate the nature or extent of such a market beyond the interview data.

\subsubsection{Shark Population Trends}

Our respondents reported mixed and contradicting views regarding shark population abundance in Belize. A number of stakeholders from our different stakeholder groups recalled larger shark sizes 
and greater numbers of sharks in the area 30 to 40 years ago. A former Minister of Fisheries supported this view: "way back maybe in the "70s. A lot of big sharks used to be landed right here in PG." Out on the barrier reef, but still in the area of Punta Gorda, the same observations were reported (see Table 3). Further up the coast, stakeholders in Placencia also described a decline in shark populations. As an alternative explanation to a population decline, some respondents felt that sharks might be migrating away from an area. In doing so, it would appear as a decline. The depletion of fish prey stocks and abandoned chumming practices emerged as major themes to explain movement away from their usually seen places. Many respondents described chumming practices in Laughing Bird Caye National Park and around the Silk Cayes and how it would attract sharks, to the point that some referred to sharks as 'trained'. A sign prohibiting chumming is now visible on Laughing Bird Caye.

In contrast, some stakeholders had strong opinions about shark populations increasing, especially recently: "It got bigger [the population]. A hell lot more too [... ] where we fish in Gladden Spit, there I know it's getting bigger" explained a young Placencia fisher in reference to the Gladden Spit and Silk Cayes Marine Reserve, an important fishing ground in Belize and known spawning aggregation for snapper species_shark prey. Fishers and non-fishers both reported seeing more sharks on the reef. At the government level, a Belize Fisheries Department officer summarized that the reports they obtained from stakeholders exemplify important gaps and challenges facing shark conservation in Belize: "there's a concern, mainly because we, we are lacking most of the landings information, [ ... ] we have, I would say, anecdotal information that there has been a decline on shark but we do not have the data to back that up. [...] Fishers are telling us that this is not the case, that there's a lot of sharks out there you know. [...] we are lacking the human resources, financial resources [... ] I think we need a more in-depth science."

\subsubsection{Shark Conservation Measures}

Sharks were strongly perceived as being a threat to the livelihoods of most fishers we interviewed. Snapper are a Belizean favorite, the most sought after fish species and among the most lucrative catch to fishers: "everybody likes snappers, it's still the favorite, I don't think that will change". Fishers and respondents in the tourism, government and NGO sectors repeatedly described the high competition with sharks for snapper. Most snapper fishers we interviewed would prefer to see no sharks in the oceans and insisted that their population has increased and that it's harder to catch snapper. A younger fisher from Placencia explained how she would feel if sharks were protected: "terrible, cause we won't get any fish". Fishers often reported bigger sharks, more aggressive behavior, and a decline in their catch, making their job harder (see Table 3).

Many fishers in our sample had held multiple sources of employment, with some working in the tourism industry (e.g., as tour guides, SCUBA instructors, boat captains) or in the non-government sector (e.g., rangers or park managers). Most respondents in this group continued to fish or revert to fishing for livelihood support when tourism was slow, or during the lucrative snapper and/or lobster and/or conch seasons. These fishers reported that sharks are important, but insisted that there should be a balance in their population, which they felt is not the case, generally describing too many sharks on the reef, and that sharks compete with their catch, particularly snapper, and therefore their livelihood. Some felt that no study had been done, and that the fishers were supposed to just accept what researchers tell them (see Table 3). A nationalized Guatemalan-Belizean fisher explained that if sharks show the need for protection he agrees, but since they reproduce, like any other marine product, that they should be allowed to fish them. He was in favor of sharks being protected to some extent, but said that researchers don't want them to fish sharks at all, and that traditional fishers were against this.

Numerous respondents believed that there was no scientific evidence of shark population decline, that they did not receive the results of shark-related research, and that they were dictated laws without supporting evidence. They described being opposed to a protection law not because they believed the resources were sustainable, but because of the ways in which they felt a protection policy would happen (Table 3). Following the theme that fishers felt uninformed on species populations, a few were neutral on shark conservation issues because they could not decide whether shark protection was 
needed, as this respondent from Placencia explained: "for me it's kind of touchy and the thing is because I'm not filled with enough scientific information" Others believed that there should be laws for some species only, as noted by this senior Placencia traditional fisher: "but shark is a big thing they need to decline, they need to decline sharks, just different species like the Hammerhead I don't think they should. Hammerhead we no gat lot."

Unlike many of the fishers we interviewed, tourist operators generally felt that sharks should be conserved. Many were sensitive to the ecological role of sharks and the consequences of their absence. Some respondents supported shark protection for future generations, while others were unsure about why sharks should be protected, even though they felt they should be. Sightings were considered important to tourists, some requesting to see specific species of sharks when booking a dive, as noted by this SCUBA instructor and former shark fisher: "if there's a decrease in a species it affects Belize because ... this is the income in tourism, a lot of people demand specific sharks [... ] some people come and they request, I want to see Hammerhead." These respondents associated shark sightings with a healthy reef, which is important to tourism: "sharks are very, very important, like I mentioned it's one of top predator, [ ... ] they clean the reef, [ ... ], they're the John Crow of the sea." Other respondents were unsure due to the fact that they did not know how their populations were doing and that there should be more discussions.

\subsection{Influence of Stakeholders in Affecting Shark Conservation in Belize}

Fishers were described as having a high degree of influence over policies from both their own point of view and the view of other stakeholders. Our respondents perceived fishers as being able to work regulations to their advantage and retract others that are deemed to challenge their livelihood. They were also seen as being able to influence the Belize Fisheries Department with their views of sharks. Fishers were seen as exerting considerable influence on the Fisheries Advisory Board, who represent them through fisher cooperatives, when advising the Belize Fisheries Department or during consultations for new policies and management strategies. When asked whether their opinions were acknowledged, a senior traditional fisher with training in marine biology explained: "oh yes! Fishermen have very strong opinions [laughing]". They have also been influential with their leadership establishing marine reserves in the country. A former NGO administrator and now government officer explained fishers' strong influence in politics: "Belize is a small country and because of the accessibility of our politicians, it means that fishermen have access to them and they are a lobby [ . . ] they always have a chance to input into policies". This was also the view of our government respondents. A former Minister of Fisheries also explained the influence of the fisher cooperative "[..] they are the ones that actually control the sea and the policy of the sea, because they determine policy, they work along with the Fisheries Department, they sat on the Fisheries Advisory Board to the Minister, so whatever policy was made was made on that table with them as participants and they determine closed season, open seasons for conchs, for crayfish and that kind of thing."

Fishers were also seen as having an influence on the Belize Fisheries Department when it came to assessing shark abundance and any measures related to their conservation. Fisheries officers indicated that they were not sure about the current situation of shark fisheries in Belize or about their current population size. They also were uncertain about the quantity of sharks exported, receiving anecdotal information that they were declining in some areas, however fishers reported that there were too many. It was often mentioned that regulations were more easily passed when fishers were not in opposition. Examples included the protection of the Whale shark as this regulation may have advantaged the fishers though indirectly fighting illegal fishers from Guatemala and Honduras, through generating money for enforcement via tourism. More recently, local fishers had recommended that the Nurse shark be protected.

Although fishers were seen as having strong influence over policies, it was not clear how this was organized. Based on our interviews, we were able to identify the following subgroups: (1) Belize-born traditional fishers; (2) nationalized traditional fishers (often dual citizens of Honduras-Belize and Guatemala-Belize); (3) opportunistic fishers; and (4) fishers that move between various stakeholder groups. Among these subgroups, it appeared that traditional (small scale and local) fishers were well 
placed to protect their livelihood from opportunistic fishers. Despite this, the majority of traditional fishers we interviewed did not feel they had a high degree of influence in the socio-political system, mainly due to within-group division: "one of the problem I see with the fishermen especially here in Toledo, they are divided [ ... ] they'll divide the fishermen and you know divide and conquer [... ] it's a riot amongst themselves."

Many fishers in our sample described having no voice, being imposed laws that limit their livelihood, being exploited for their long-term knowledge and experience and being tricked by NGOs and researchers because their knowledge gets used to close fishing grounds. They also expressed frustration with not having scientific research findings communicated to them and being 'used' to obtain research funding that they never received. In Punta Gorda, there was a lot of resentment surrounding the origins of the Port Honduras Marine Reserve. A traditional fisher explained how fishers felt betrayed and used to obtain fisher knowledge and signatures to establish what is now the Port Honduras Marine Reserve, in exchange for promised funding to send their kids to university to obtain the skills to diversify their livelihoods, however this reportedly did not happen and now their children are forced to become fishers: "it's our biggest problem right now for our fishermen to send our children to school [... ] You see this da wa problem because opening wa marine reserve and start conservation and thing and den we, the fisherman can't benefit outa it [ ... ] No benefit is there for us because our children is not going to school". Our interviewees also reported that only fishers that would vote in favor of an organization's goals are often invited to meetings, meaning that many fishers didn't have a voice. Our key informant traditional fishers repeatedly described feeling as though they come second to foreign and even illegal fishers in the country, and also to those who have not been fishing their entire life in the same area.

Considerable influence to push for shark conservation was described as coming from stakeholders outside Belize, or non-Belizeans with a stake in Belize. Regional Fisheries Management Organizations (RFMOs) were identified as having a high degree of influence. Another reason for the high level of influence enjoyed by external stakeholders was funding. For example, the Belize Fisheries Department has only recently had the means to start looking into shark protection, however there still remains challenges, mainly human and monetary resources: "We really don't have the resources to, conduct the data collection. [ ... ] and the subsequent data analysis" explained a Fisheries officer. Funding was also mentioned as a major challenge for local research institutions to fill gaps in knowledge. Based on our previous findings, this issue has significant implications for justifying shark conservation measures to different stakeholders. When it comes to influencing domestic policies, foreigners were seen as having a strong ability to push for their interests. For example, a recurring theme that also articulated frustration amongst fishers and some tour guides was that 'White' people get away with everything in Belize: whether it's buying protected areas, or not having to abide by the rules, or changing existing laws to their advantage. Respondents also speculated that stakeholders in Asia were having a significant impact on shark protection policies in Belize.

\section{Discussion}

Addressing gaps in our knowledge of social systems has been recognized as essential for the sustainable conservation and management of shark species [79-81]. According to Techera and Klein [82], social science research on shark conservation and management is nascent, with concerted multi-disciplinary effort needed to understand the multiple stakeholders involved. Our exploratory research responds to this call, and offers novel insight to some of the different and overlapping relationships that exist between stakeholders and sharks in Belize. Collaboration between government, the fishing industry and markets has also been previously identified as missing in shark conservation and management, with opportunities to work more directly with shark supply chains often overlooked [83]. There remains a general need for the "development of marine policy that recognizes and takes into consideration all members of the user community and addresses current, multiple, interacting uses" [38] in order to improve the legitimacy and credibility of shark conservation policy and management 
efforts $[39,69,84]$. It is within this global context that the present study offers valuable insights to some of the challenges facing the collaborative governance [85] of precious shark resources in Belize. For shark conservation and management, governance concerns how people integrate the interests and concerns of multiple public and private stakeholders to address shared issues [86]. It is also about the processes that support governance such as fostering learning and building civic and political will [87]. Collaborative approaches to governance become essential when complex issues need to be addressed at several scales simultaneously, when issues transcend existing jurisdictions, organizations and institutions and when no single entity has the power or authority to address cross-boundary issues, leading to gaps in governance $[86,88,89]$. The diverging viewpoints we found concerning shark population trends, illegal and unreported fishing activities and market demand for shark products within Belize, combined with a general perception that not enough scientific information is available to support action, suggest major social barriers to realizing collaborative governance among the stakeholders involved in shark conservation and management.

Lawrence [83] argues that a new paradigm is needed to drive change and transform the operating environment in which sharks are caught, traded and consumed. Collaborative governance offers such a paradigm, and requires the reciprocal exchange of information and knowledge between diverse policy actors through formal and informal communication networks in order to "... exchange ideas, build relationships, identify common interests, explore options on how to work together, share power, and solve problems of mutual interest" [86]. In our study, information and knowledge gaps were repeatedly highlighted as being a barrier to realizing more collaboration, including by respondents from the Belize Fisheries Department, particularly regarding shark populations and the quantum of sharks being landed and taken out of Belize waters (both legally and illegally). Innovative and creative ways to help address these information and knowledge gaps within existing management and budgetary constraints are needed to help inform stakeholder discourses, promote mutual learning and enhance the coordination of policy design, implementation and enforcement [23]. Confusion over the population status of sharks in Belize appeared as a particularly significant barrier to improving shark conservation and management in our study. Regionally, there also appeared to be a need for greater inter-jurisdictional communication and collaboration in support of shark conservation and management policy; with regulation and monitoring gaps identified by respondents in relation to the strong regional and international demand for shark products driving illegal and unreported fisheries in Belize waters [28]. These findings support Lawrence [83] who argues that new opportunities for collaborative approaches to tackling the international shark crisis urgently need to be explored. To this end, further research into the potential for transboundary network governance approaches (such as those already trialed and adopted in other complex transboundary fishery settings [90]) to enhance the conservation and management of shark resource systems along the Mesoamerican Barrier Reef would be valuable.

Generally, there was confusion among the stakeholders we interviewed on whether sharks were already protected or not, and whether there was any evidence of shark population declines. All stakeholders described a desire to receive more information and addressing this issue could have a significant impact on the social discourse surrounding shark conservation policy in Belize. For example, most stakeholders we interviewed were not necessarily opposed to protecting sharks if the science showed that it was necessary; however, the majority felt that the science was not there to support such a decision. We also observed a high level of distrust of foreign scientists and research organizations within the community. Many respondents expressed frustration because they felt that marine researchers often came into the country, collected their knowledge, promised to return with their findings and never did. In particular, fishers expressed that they felt exploited and even abused by researchers and non-governmental organizations. As noted by Smith et al. [91], many of the challenges faced in natural resource management can be resolved by increasing public engagement and trust within the community. This involves recognizing community participation as protocol, and increasing communication, the sharing of information and joint-goal setting at the development 
stage of research $[92,93]$. Adopting more cooperative approaches to fisheries research in this way also has the potential to increase trust and foster longer-lasting partnerships between reef scientists and reef stakeholders [94-96]. Additional opportunities to enhance the public impact of shark science in Belize include the formal acknowledgment and incorporation of local traditional knowledge [97], the creation and maintenance of open access data repositories and the co-design of stakeholder outreach and engagement platforms. Here, the aim should be to create informal and formal ways for reciprocal information flow in order to enable stakeholders to work more effectively across cultural, epistemic, organizational, jurisdictional, political, ecological and institutional boundaries and enhance collaborative governance processes and outcomes [86].

We also found that perceived levels of policy influence vary considerably amongst stakeholders, with stakeholders external to Belize and local fishers viewed as having the greatest influence in domestic public policy processes. Further, the stakeholder groups interested in shark policy appeared to be tightly interconnected. In terms of fishers, further research to better understand and characterize the wide variety of fishers operating in Belize could help legal frameworks, public policies and stakeholder consultation processes to more appropriately consider and reflect the diversity of interests, rights and responsibilities of all fishers in shark conservation and management. Importantly, informal groupings among fishers will likely have changing membership with ad hoc coalitions emerging in response to events [98], again suggesting the potential value of more decentralized and network approaches to collaborative shark resource governance [88], potentially using existing mechanisms such as the Fisheries Advisory Board and the Belize Fisheries Corporative Association. While shark conservation measures that include the establishment of inclusive policy frameworks, marine protected areas and enhanced monitoring and enforcement will remain important, sustainable outcomes also depend heavily on whether demand for shark products can be reduced [83]. Our respondents attributed high importance to the regional and international demand for shark products as driving illegal and unregulated shark fisheries in Belize, again suggesting the need for greater collaborative efforts to address the marketing and trade of shark products nationally, regionally and internationally. Recent relevant developments include a National Shark Workshop held in 2017 to update the National Plan of Action-Sharks for Belize by a new National Working Group that was established in 2016. This workshop was then followed by the first meeting of several Regional Fisheries Management Organisations (RFMOs), the United Nations Food and Agriculture Organisation (FAO) and other regional groups for the first meeting of the WECAFC/OSPESCA/CRFM/CITES/CFMC working group on shark conservation and management [99], convened by the Belize Fisheries Department. These interlinked and evolving transboundary initiatives represent new and exciting opportunities for experimentation with collaborative governance in the region, however they will also require careful management in order to deliver sustainable outcomes [23]. Future research into the inter-organizational collaboration dynamics that already exist (including factors such as influence, interdependence, communication, trust and risk) in regional shark conservation and management networks has the potential to usefully inform management strategies and potentially enhance their performance [100].

\section{Conclusions}

This study sheds light on the use of sharks fished in Belizean waters, from the local to the international, describes conflicting perceptions on the status of this transboundary common pool resource as well as mixed attitudes towards formal shark protection measures. Our results also point to important gaps in knowledge and governance challenges, some of which can help to explain the different perceptions of stakeholders toward shark conservation. Taken as a whole, the analysis provides a useful and grounded glimpse into the some of the complex factors affecting shark and marine resource management in Belize, and how the perceptions and positions of stakeholders can potentially affect collaborative governance outcomes. Ultimately, there is a need for further research into the social factors affecting shark conservation and management outcomes on the Mesoamerican Barrier Reef focused at the regional transboundary level. Here, the perceptions, interests, networks 
and influence of external policy actors such as Regional Fisheries Management Organizations and foreign stakeholders in Guatemala, Honduras, Mexico and China need to be further assessed.

Author Contributions: Conceptualization, S.M.S. and G.M.H.; methodology, S.M.S. and G.M.H.; data collection, S.M.S. and G.M.H.; formal analysis, S.M.S.; resources, S.M.S. and G.M.H.; writing — original draft preparation, S.M.S.; writing—review and editing, G.M.H.; visualization, S.M.S.; supervision, G.M.H.; funding acquisition, G.M.H. and S.M.S. All authors have read and agreed to the published version of the manuscript.

Funding: Internal Social Science and Humanities Research Grant, McGill University; William Dawson Scholar Award, McGill University (G.M.H.).

Acknowledgments: An earlier version of our study was presented orally at the 12th International Coral Reef Symposium, Cairns, Queensland, Australia. 9-13 July 2012. We kindly acknowledge all the stakeholders who donated their valuable time to our interviews and focus groups and trusted us enough to share their valuable knowledge. We also gratefully acknowledge research assistants Vildo Selgado and Mark Tucker for their important role as gatekeepers and helping with field research, and Melanie McField for her support. We are grateful to Soila Bejerano and the Southern Environmental Association for providing comfortable venues for our focus groups. Thanks also to Linda Garcia and Randy Tucker for showing us Gladden Spit and Silk Cayes Reserve.

Conflicts of Interest: The authors declare no conflict of interest. The funders had no role in the design of the study; in the collection, analyses, or interpretation of data; in the writing of the manuscript, or in the decision to publish the results.

\section{References}

1. Friedlander, A.M.; De Martini, E.E. Contrasts in Density, Size, and Biomass of Reef Fishes Between the Northwestern and the main Hawaiian Islands: The Effects of Fishing Down Apex Predators. Mar. Ecol. Prog. Ser. 2002, 230, 253-264. [CrossRef]

2. White, W.T.; Kyne, P.M. The Status of Chondrichthyan Conservation in the Indo-Australasian Region. J. Biol. 2010, 76, 2090-2117. [CrossRef]

3. Cortés, E. Standardized Diet Compositions and Tropic Levels of Sharks. ICES J. Mar. Sci. 1999, 56, 707-717. [CrossRef]

4. Sandin, S.A.; Smith, J.E.; De Martini, E.E.; Dinsdale, E.A.; Donner, S.D.; Friedlander, A.M.; Konotchick, T.; Malay, M.; Maragos, J.E.; Obura, D.; et al. Baselines and Degradation of Coral Reefs in the Northern Line Islands. PLoS ONE 2008, 3, e1548. [CrossRef] [PubMed]

5. Godin, A.C.; Worm, B. Keeping the Lead: How to Strengthen Shark Conservation and Management Policies in Canada. Mar. Policy 2010, 34, 995-1001. [CrossRef]

6. Campana, S.E.; Joyce, W.; Marks, L. Population Dynamics of the Portbeagle in the Northwest Atlantic Ocean. N. Am. J. Fish. Manag. 2002, 22, 106-121. [CrossRef]

7. Baum, J.K.; Myers, R.A.; Kehler, D.G.; Worm, B.; Hartley, S.J.; Doherty, P.A. Collapse and Conservation of Shark Populations in the Northwest Atlantic. Science 2003, 299, 389-392. [CrossRef] [PubMed]

8. Myers, R.A.; Worm, B. Rapid Worldwide Depletion of Predatory Fish Communities. Nature 2003, 423, 280-283. [CrossRef] [PubMed]

9. Verlecar, X.N.; Desai, S.R.S.; Dhargalkar, V.K. Shark Hunting-An Indiscriminate Trade Endangering Elasmobranchs to Extinction. Curr. Sci. India 2007, 8, 1078-1082.

10. Compagno, L.J.V. Alternative Life-History Styles of Cartilaginous Fishes in Time and Space. Environ. Biol. Fish. 1990, 28, 33-75. [CrossRef]

11. Oliver, S.P.; Grothues, T.M.; Williams, A.L.; Cerna, V.; Silvosa, M.; Cases, G.; Reed, M.; Christopher, S. Risk and resilience: High stakes for sharks making transjurisdictional movements to use a conservation area. Biol. Conserv. 2019, 230, 58-66. [CrossRef]

12. Stevens, J.D.; Bonfil, R.; Dulvy, N.K.; Walker, P.A. The Effects of Fishing on Sharks, Rays, and Chimaeras (Chondrichthyans), and the Implications for Marine Ecosystems. ICES J. Mar. Sci. 2000, 57, 476-494. [CrossRef]

13. Robbins, W.D.; Hisano, M.; Connolly, S.R.; Choat, J.H. Ongoing Collapse of Coral-Reef Shark Populations. Curr Sci Inda 2006, 16, 2314-2319. [CrossRef] [PubMed]

14. Graham, N.A.J.; Spalding, M.D.; Sheppard, C.R.C. Reef shark Declines in Remote Atolls Highlight the Need for Multi-Faceted Conservation Action. Aquat. Conserv. 2010, 20, 543-548. [CrossRef] 
15. Ward-Paige, C.A.; Mora, C.; Lotze, H.K.; Pattengill-Semmens, C.; McClenachan, L.; Arias-Castro, E.; Myers, R.A. Large-scale Absence of Sharks on Reefs in the Greater-Caribbean: A Footprint of Human Pressures. PLoS ONE 2010, 5, e11968. [CrossRef]

16. Jackson, J.B.C.; Kirby, M.X.; Berger, W.H.; Bjorndal, K.A.; Botsford, L.W.; Bourque, B.J.; Bradbury, R.H.; Cooke, R.; Erlandson, J.; Estes, J.A.; et al. Historical overfishing and the recent collapse of coastal ecosystems. Science 2001, 293, 629-638. [CrossRef]

17. Ferretti, F.; Worm, B.; Britten, G.L.; Heithaus, M.R.; Lotze, H.K. Patterns and Ecosystem Consequences of Shark Declines in the Ocean. Ecol. Lett. 2010, 13, 1055-1071. [CrossRef]

18. Food and Agriculture Organization of the United Nations. Fisheries and Aquaculture Department. International Plan of Action for Conservation and Management of Sharks; FAO: Rome, Italy, 1999. Available online: http://www.fao.org/fishery/ipoa-sharks/en (accessed on 12 December 2019).

19. Musick, J.A.; Burgess, G.; Cailliet, G.; Camhi, M.; Fordham, S. Management of sharks and their relatives (Elasmobranchii). Fisheries 2000, 25, 9-13. [CrossRef]

20. Musick, J.A.; Berkeley, S.A.; Cailliet, G.M.; Camhi, M.; Huntsman, G.; Nammack, M.; Warren, M.L., Jr. Protection of Marine Fish Stocks at Risk of Extinction. Fisheries 2000, 25, 6-8. [CrossRef]

21. Heithaus, M.R.; Frid, A.; Wirsing, A.J.; Worm, B. Predicting Ecological Consequences of Marine Top Predator Decline. Trends Ecol. Evol. 2007, 23, 202-221. [CrossRef]

22. Speed, C.W.; Field, I.C.; Meekan, M.G.; Bradshaw, C.J.A. Complexities of Coastal Shark Movements and their Implications for Management. Mar. Ecol. Prog. Ser. 2010, 408, 275-293. [CrossRef]

23. Techera, E.J.; Klein, N. Fragmented Governance: Reconciling Legal Strategies for Shark Conservation and Management. Mar. Policy 2011, 35, 73-78. [CrossRef]

24. Castillo-Géniz, J.L.; Márquez-Farias, J.F.; de la Rodriguez Cruz, M.C.; Cortéz, E.; del Cid Prado, A. The Mexican Artisanal Shark Fishery in the Gulf of Mexico: Towards a Regulated Fishery. Mar. Freshw. Res. 1998, 49, 611-620. [CrossRef]

25. Dutton, P.H.; Sarti, L.; Márquez, R.; Squires, D. Sea Turtle Conservation across the Shared Marine Border. In Both Sides of the Border: Transboundary Environmental Management Issues Facing Mexico and the United States-Economics of Non-Market Goods and Resources; Batema, J.J., Fernandez, L., Carson, R.T., Eds.; Springer: Berlin/Heidelberg, Germany, 2003; Volume 2.

26. Lugten, G. The Role of International Fishery Organizations and Other Bodies in the Conservation and Management of Living Aquatic Resources. In FAO Fisheries and Aquaculture Circular; FAO: Rome, Italy, 2010; p. 123, No. 1054 .

27. Cavanagh, R.D.; Fowler, S.L.; Camhi, M.D. Pelagic Sharks and the FAO International Plan of Action for the Conservation and Management of Sharks. In Sharks of the Open Ocean: Biology, Fisheries and Conservation; Camhi, M.D., Pikitch, E.K., Babcock, E.A., Eds.; Blackwell Publishing: Oxford, UK, 2008; pp. 478-492.

28. Carr, L.A.; Stier, A.C.; Fietz, K.; Montero, I.; Gallagher, A.J.; Bruno, J.F. Illegal Shark Fishing in the Galapagos Marine Reserve. Mar. Policy 2013, 39, 317-321. [CrossRef]

29. Frisch, A.J.; Rizzari, J.R. Parks for Sharks: Human Exclusion Areas Outperform No-Take Marine Reserves. Front. Ecol. Environ. 2019, 7, 145-150. [CrossRef]

30. MacKeracher, T.; Diedrich, A.; Simpfendorfer, C.A. Sharks, rays and marine protected areas: A critical evaluation of current perspectives. Fish Fish. 2019, 20, 255-267. [CrossRef]

31. Salomón-Aguilar, C.A.; Villavicencio-Garayzar, C.J.; Reyes-Bonilla, H. Shark breeding grounds and seasons in the Gulf of California: Fishery management and conservation strategy. Cienc. Mar. 2009, 35, 369-388. [CrossRef]

32. Thomassin, A.; White, C.S.; Stead, S.S.; David, G. Social Acceptability of a Marine Protected Area: The case of Reunion Island. Ocean Coast. Manag. 2010, 53, 169-179. [CrossRef]

33. Herndon, A.; Gallucci, V.F.; De Master, D.; Burke, W. The case for an international commission for the conservation and management of sharks (ICCMS). Mar. Policy 2010, 34, 1239-1248. [CrossRef]

34. Dell'Apa, A.; Smith, M.C.; Kaneshiro-Pineiro, M.Y. The influence of culture on the international management of shark finning. Environ. Manag. 2014, 54, 151-161. [CrossRef]

35. Byers, J.E.; Noonburg, E.G. Poaching, Enforcement, and the Efficacy of Marine Reserves. Ecol. Appl. 2007, 17, 1851-1856. [CrossRef] [PubMed]

36. Pascoe, S.; Proctor, W.; Wilcox, C.; Innes, J.; Rochester, W.; Dowling, N. Stakeholder objective preferences in Australian Commonwealth managed fisheries. Mar. Policy 2009, 33, 750-758. [CrossRef] 
37. Rastogi, A.; Hickey, G.M.; Badola, R.; Hussain, S.A. Saving the superstar: A review of the social factors affecting tiger conservation in India. J. Environ. Manag. 2012, 113, 328-340. [CrossRef] [PubMed]

38. Atkins, J.P.; Burdon, D.; Elliott, M.; Gregory, A.J. Management of the Marine Environment: Integrating Ecosystem Services and Societal Benefits with the DPSIR Framework in a Systems Approach. Mar. Pollut. Bull. 2011, 62, 215-226. [CrossRef]

39. Grimble, R.; Chan, M.-K. Stakeholder analysis for natural resource management in developing countries: Some practical guidelines for making management more participatory and effective. Nat. Resour. Forum. 1995, 19, 113-124. [CrossRef]

40. Bandara, R.; Tisdell, C. Comparison of rural and urban attitudes to the conservation of Asian elephants in Sri Lanka: Empirical evidence. Biol. Conserv. 2003, 110, 327-342. [CrossRef]

41. Cinner, J.E.; Pollnac, R.B. Poverty, perceptions and planning: Why socioeconomics matter in the management of Mexican reefs. Ocean Coast. Manag. 2004, 47, 479-493. [CrossRef]

42. Windevoxhel, N.J.; Rodríguez, J.J.; Lahmann, E.J. Situation of Integrated Coastal Zone Management in Central America: Experiences of the IUCN Wetlands and Coastal Zone Conservation Program. Ocean Coast. Manag. 1999, 42, 257-282. [CrossRef]

43. Cooper, E.; Burke, L.; Bood, N. Coastal Capital: Belize. The Economic Contribution of Belize's Coral Reefs and Mangroves. In WRI Working Paper; World Resources Institute: Washington, DC, USA, 2009; p. 53.

44. Gibson, J.; McField, M.; Wells, S. Coral Reef Management in Belize: An Approach through Integrated Coastal Zone Management. Ocean Coast. Manag. 1998, 39, 229-244. [CrossRef]

45. Gibson, J. The Belize Barrier Reef: A World Heritage Site. In Too Precious to Drill: The Marine Biodiversity of Belize; Palomares, M.L.D., Pauly, D., Eds.; Fisheries Centre Research Reports; Fisheries Centre, University of British Columbia: Vancouver, BC, Canada, 2011; Volume 19, pp. 8-13.

46. Pikitch, E.K.; Chapman, D.D.; Babcock, E.A.; Shivji, M.S. Habitat Use and Demographic Population Structure of Elasmobranchs at a Caribbean Atoll (Glover's Reef, Belize). Mar. Ecol. Prog. Ser. 2005, 302, 187-197. [CrossRef]

47. Chapman, D.D.; Pikitich, E.K.; Babcock, E.A.; Shivji, M.S. Deep-diving and Diel changes in vertical habitat by Caribbean Reef sharks Carcharhinus perezi. Mar. Ecol. Prog. Ser. 2007, 344, 271-275. [CrossRef]

48. Rosa, R.S.; Mancini, P.; Caldas, J.P.; Graham, R.T. Carcharhinus perezi. IUCN Red List of Threatened Species 2006. Available online: http://www.iucnredlist.org/apps/redlist/details/60217/0 (accessed on 4 October 2010).

49. Red List of Threatened species. IUCN Red List. Available online: https://www.iucnredlist.org/ (accessed on 26 October 2019).

50. Government of Belize. Fisheries Act, Chapter 210. In Chapter 3 of the Sustantive Laws of Belize; Revised Ed.; Subsidiary Laws (2003), prepared by the Law Revision Commissioner; Government of Belize: Belmopan, Belize, 2000.

51. Government of Belize. Fisheries—Statutory Instrument. No. 78 of 2011. In Fisheries; (Amendment) (No. 2) Regulation; Government of Belize: Belmopan, Belize, 2011.

52. Saberwal, V.K.; Rangarajan, M.; Kothari, A. People, Parks and Wildlife: Towards Coexistence; Orient Longman: New Dehli, India, 2001.

53. Wilshusen, P.R.; Brechin, S.R.; Fortwangler, C.F.; West, P.C. Reinventing a Square Wheel: Critique of a Resurgent "Protection Paradigm" in International Biodiversity Conservation. Soc. Nat. Resour. 2002, 15, 17-40. [CrossRef]

54. Glaser, B.G.; Strauss, A.L. The Discovery of Grounded Theory: Strategies for Qualitative Research; Aldine Publishing Company: Chicago, IL, USA, 1967.

55. Goulding, C. Grounded Theory: Some Reflections on Paradigm, Procedures and Misconceptions; Working Paper Series June 1999; Wolverhampton Business School-Management Research Center: University of Wolverhampton: Wolverhampton, UK, 1999.

56. Yin, R.K. Case Study Research: Design and Methods; Safe Publications: Thousand Oaks, CA, USA, 2009.

57. Charmaz, K. Constructing Grounded Theory: A Practical Guide Through Qualitative Analysis; Sage Publications: Thousand Oaks, CA, USA, 2006.

58. Government of Belize. National Plan of Action-Conservation and Management of Sharks on the High Seas. In Belize High Seas Fisheries Unit; Government of Belize: Belmopan, Belize, 2015.

59. Peedle, I. Belize: A Guide to the People, Politics and Culture. In Focus Series; Interlink Books: Brooklyn, NY, USA, 1999; p. 100. 
60. Moreno, P.S. Ecotourism along the Meso-American Caribbean Reef: The Impact of Foreign Investment. Hum. Ecol. 2005, 33, 217-244. [CrossRef]

61. Escure, G. Garifuna in Belize and Honduras. In Creoles, Contact and Language Change: Linguistic and Social Implications; Escure, G., Schwegler, A., Eds.; Creole Language Library Volume 27; John Benjamins Publishing Company: Amsterdam, The Netherlands, 2004. [CrossRef]

62. Key, C.J. The Political Economy of the Transition from Fishing to Tourim, in Placencia, Belize. Int. Rev. Mod. Sociol. 2002, 30, 1-17.

63. Rubin, H.S.; Rubin, I.S. Qualitative Interviewing: The Art of Hearing Data, 2nd ed.; Sage Publications: Thousand Oaks, CA, USA, 2005.

64. Emerson, R.; Pollner, M. Constructing Participant/Observation Relations. In Contemporary Field Research: Perspectives and Formulations, 2nd ed.; Emerson, R., Ed.; Waveland Press: Long Grove, IL, USA, 2001; pp. 239-259.

65. Hennink, M.M. International Focus Group Research: A Handbook for the Health and Social Sciences; Crambridge University Press: New York, NY, USA, 2007.

66. Krueger, R.A.; Casey, M. Focus Groups: A Practical Guide for Applied Research, 4th ed.; Sage Publications: Thousand Oaks, CA, USA, 2009.

67. Creswell, J.W. Research Design: Qualitative, Quantitative, and Mixed Methods Approaches, 3rd ed.; Sage Publications: Thousand Oaks, CA, USA, 2009.

68. Grimble, R.; Wellard, K. Stakeholder Methodologies in Natural Resource Management: A Review of Principle, Contexts, Experiences and Opportunities. Agric. Syst. 1997, 55, 173-193. [CrossRef]

69. Schmeer, K. Guidelines for Conducting a Stakeholder Analysis. In Partnerships for Health Reform; Bethesda, M.D., Ed.; Abt Associates Inc.: Cambridge, MA, USA, 1999.

70. Yin, R.K. Qualitative Research from Start to Finish; The Guildford Press: Guildford, CT, USA, 2011.

71. Creswell, J.W.; Miller, D. Determining validity in qualitative inquiry. Theory Pract. 2000, 39, 124-130. [CrossRef]

72. Lalor, B.M.; Hickey, G.M. Environmental science and public policy in Executive government: Insights from Australia and Canada. Sci. Public Policy 2013, 40, 767-778. [CrossRef]

73. Rastogi, A.; Badola, R.; Hussain, S.A.; Hickey, G.M. Assessing the Utility of Stakeholder Analysis to Protected Areas Management: The Case of Corbett National Park, India. Biol. Conserv. 2010, 143, 2956-2964. [CrossRef]

74. Varvasovszky, Z.; Brugha, R. How to do (or not to do) ... a stakeholder analysis. Health Policy Plan. 2000, 15, 338-345. [CrossRef]

75. Zimmermann, A.; Maennling, C. Mainstreaming Participation: Multi-Stakeholder Management: Tools for Stakeholder Analysis: 10 Building Blocks for Designing Participatory Systems of Cooperation; Deutsche Gesellschaft für: Eschborn, Germany, 2007.

76. Is Your Fillet Really Snapper? Available online: http://7newsbelize.com/sstory.php?nid=19860 (accessed on 17 June 2011).

77. Fishy Fish Fillet-Snapper or 'Kyato'? Available online: https://amandala.com.bz/news/fishy-fish-filletsnapper-or-kyato/ (accessed on 17 June 2011).

78. Cox, C.E.; Jones, C.D.; Wares, J.P.; Castillo, K.D.; McField, M.D.; Bruno, J.F. Genetic Testing Reveals some Mislabeling but General Compliance with a Ban on Herbivorous Fish Harvesting in Belize. Conserv. Lett. 2013, 6, 132-140. [CrossRef]

79. Davis, B.; Worm, B. The International Plan of Action for Sharks: How does National Implementation Measure up? Mar. Policy 2013, 38, 312-320. [CrossRef]

80. Jacques, P.J. The Social Oceanography of Top Oceanic Predators and the Decline of Sharks: A Call for a New Field. Prog. Oceanogr. 2010, 86, 192-203. [CrossRef]

81. Simpfendorfer, C.A.; Heupel, M.R.; White, W.T.; Dulvy, N.K. The Importance of Research and Public Opinion to Conservation Management of Sharks and Rays: A Synthesis. Mar. Freshw. Res. 2011, 62, 518-527. [CrossRef]

82. Techera, E.J.; Klein, N. (Eds.) Sharks: Conservation, Governance and Management; Routledge: New York, NY, USA, 2014.

83. Lawrence, A. Collaborations for conservation. In Sharks: Conservation, Governance and Management; Techera, E.J., Klein, N., Eds.; Routledge: New York, NY, USA, 2014; pp. 135-156. 
84. Worthington, T.; Tisdale, J.; Kemp, P.; Williams, I.; Osborne, P.E. Public and Stakeholder Attitudes to the Reintroduction of the Burbot, Lota lota. Fish. Manag. Ecol. 2010, 17, 465-472. [CrossRef]

85. Emerson, K.; Nabatchi, T.; Balogh, S. An Integrative Framework for Collaborative Governance. J. Public Adm. Res. Theory 2012, 22, 1-29. [CrossRef]

86. Scarlett, L.; McKinney, M. Connecting People and Places: The Emerging Role of Network Governance in Large Landscape Conservation. Front. Ecol. Environ. 2016, 14, 116-125. [CrossRef]

87. Scholz, J.T.; Stifel, B. (Eds.) Adaptive Governance and Water Conflict: New Institutions for Collaborative Planning; Resrouces for the Future: Washington, DC, USA, 2005.

88. Bixler, R.P.; Wald, D.M.; Ogden, L.A.; Leong, K.M.; Johnston, E.W.; Romolini, M. Network Governance for Large-scale Natural Resource Conservation and the Challenge of Capture. Front. Ecol. Environ. 2016, 14, 165-171. [CrossRef]

89. Leong, K.M.; Emmerson, D.P.; Byron, R. The New Governance Era: Implications for Collaborative Conservation and Adaptive Management in Department of the Interior Agencies. Hum. Dimens. Wildl. 2011, 16, 236-243. [CrossRef]

90. Song, A.M.; Temby, O.; Kim, D.; Cisneros, A.S.; Hickey, G.M. Measuring, mapping and quantifying the effects of trust and informal communication on transboundary collaboration in the Great Lakes fisheries policy network. Glob. Environ. Chang. 2019, 54, 6-18. [CrossRef]

91. Smith, P.D.; McDonough, M.H.; Mang, M.T. Ecosystem Management and Public Participation: Lessons from the field. J. For. 1999, 97, 32-38.

92. Alexander, S.E. Resident Attitudes towards Conservation and Black Howler monkeys in Belize: The Community Baboon Sanctuary. Environ. Conserv. 2000, 27, 341-350. [CrossRef]

93. Schuett, M.A.; Selin, S.W.; Carr, D.S. Making it Work: Keys to Successful Collaboration in Natural Resource Management. Environ. Manag. 2001, 27, 587-593. [CrossRef] [PubMed]

94. Bäckstrand, K. Civic Science for Sustainability: Reframing the Role of Experts, Policy-makers and Citizens in Environmental Governance. Glob. Environ. Politics 2003, 3, 24-41. [CrossRef]

95. Hartley, T.W.; Robertson, R.A. Stakeholder Engagement, Cooperative Fisheries Research and Democratic Science: The Case of the Northeast consortium. Hum. Ecol. Rev. 2006, 13, 161-171.

96. Stöhr, C.; Chabay, I. Science and Participation in Governance of the Baltic Sea fisheries. Environ. Policy Gov. 2010, 20, 350-363. [CrossRef]

97. Aswani, S.; Hamilton, R.J. Integrating Indigenous Ecological Knowledge and Customary Sea Tenure with Marine and Social Science for Conservation of Bumphead parrotfish (Bolbometopon muricarum) in the Roviana Lagoon, Solomon Islands. Exp. Conserv. 2004, 31, 69-83. [CrossRef]

98. Newcombe, R. From Client to Project Stakeholders: A Stakeholder Mapping Approach. Constr. Manag. Econ. 2003, 21, 841-848. [CrossRef]

99. Food and Agriculture Organization (FAO). Report of the First Meeting of the WECAFC/OSPESCA/CRFM/CITES/CFMC Working Group on Shark Conservation and Management. 2018. Available online: http://www.fao.org/3/i8718en/I8718EN.pdf (accessed on 11 November 2019).

100. Lima, A.; Kim, D.; Song, A.M.; Hickey, G.M.; Temby, O. Trust and influence in the Gulf of Mexico's fishery public management network. Sustainability 2019, 11, 6090. [CrossRef]

(C) 2019 by the authors. Licensee MDPI, Basel, Switzerland. This article is an open access article distributed under the terms and conditions of the Creative Commons Attribution (CC BY) license (http://creativecommons.org/licenses/by/4.0/). 